\title{
A New Record of Cymatium encausticum (Ranellidae: Tonnoidea: Gastropoda) from Korea
}

\author{
Junhee Lee ${ }^{1}$, Sang-Hwa Lee ${ }^{2}$, Jongrak Lee ${ }^{3}$, Joong-Ki Park'1,2,* \\ 'Department of Parasitology, College of Medicine, Chungbuk National University, Cheongju 361-763, Korea \\ ${ }^{2}$ Graduate Program in Cellular Biology and Genetics and Department of Parasitology, \\ College of Medicine, Chungbuk National University, Cheongju 361-763, Korea \\ ${ }^{3}$ Marine Biodiversity Research Institute, INTHESEA KOREA Inc., Jeju 697-110, Korea
}

\begin{abstract}
The Cymatium Röding, 1798 is a small- to large-sized marine gastropod genus. Three species has been reported thus far for Cymatium in the Korean waters. In general, Cymatium encausticum (Reeve, 1844) is known to occur in tropical seawaters including the Philippine Islands along with its congeners $C$. gutturnium, C. springsteeni, and C. exile. A single individual of the species was collected from Jejudo Island by SCUBA diving and morphological features were observed using a stereomicroscope. This is the first study to report the occurrence of Cymatium encausticum (Reeve, 1844) from the Korean waters, providing a detailed description of the species with the illustration for the shell morphology.
\end{abstract}

Keywords: Cymatium encausticum, new record, taxonomy, Jejudo Island, Korea

\section{INTRODUCTION}

The Cymatium Röding, 1798 is a small- to large-sized marine gastropod genus, ranging from a few cm to nearly $20 \mathrm{~cm}$ in shell height. It contains approximately a hundred species (the number of species is variable according to the taxonomic authorities), many of which are found in tropical waters (Henning and Hemmen, 1993). Cymatium is carnivorous that normally feeds on a variety of invertebrates, such as tube worms, ascidians, and other bivalve mollusks, including clams and oyster species (Houbrick and Fretter, 1969; Littlewood, 1989; Govan, 1995). The external morphology of this genus is characterized by having a club-shaped shell with an ornamentation of knob, spiral ribs, and axial varices. To date, three Cymatium species have been reported in the Korean waters: Cymatium parthenopeum echo Kuroda and Habe, 1961, C. comptum (Adams, 1855), and C. tenuiliratum (Lischke, 1873).

In this study, we report a new record of Cymatium encausticum (Reeve, 1844) in the Korean waters, providing a description of the species with illustration for the shell morphology. A single individual of the species was collected from
Jejudo Island at a depth of 9 meters by SCUBA diving on November 2010 and transferred to the laboratory after a fixation in $95 \%$ ethanol. Morphological features were observed using a stereomicroscope (Leica MZ12.5, Germany). The specimen used in this study was deposited (registration no. G00000106) in the Marine Mollusk Resources Bank of Korea (MMRBK) at Chungbuk National University in Korea.

\section{SYSTEMATIC ACCOUNTS}

Class Gastropoda Cuvier, 1797

Superfamily Tonnoidea Suter, 1913

Family Ranellidae Gray, 1854

Subfamily Cymatinae Iredale, 1913 (1854)

Genus Cymatium Röding, 1798

${ }^{1 *}$ Cymatium encausticum (Reeve, 1844) (Fig. 1)

Triton encausticus Reeve, 1844: P1. 12, fig. 43.

Cymatium pyriformia: Yen, 1942: 215, Pl. 18, fig. 111.

Ranularia encaustica: Habe, 1964: 72, Pl. 22, fig. 15.

Korean name: ${ }^{1 *}$ 곤봉수염고둥 (신칭)

(c) This is an Open Access article distributed under the terms of the Creative Commons Attribution Non-Commercial License (http://creativecommons.org/ licenses/by-nc/3.0/) which permits unrestricted non-commercial use, distribution, and reproduction in any medium, provided the original work is properly cited.

pISSN 2234-6953 eISSN 2234-8190
*To whom correspondence should be addressed

Tel: 82-43-261-2843, Fax: 82-43-272-1603

E-mail: jkpyou@chungbuk.ac.kr; jkpyou@gmail.com 


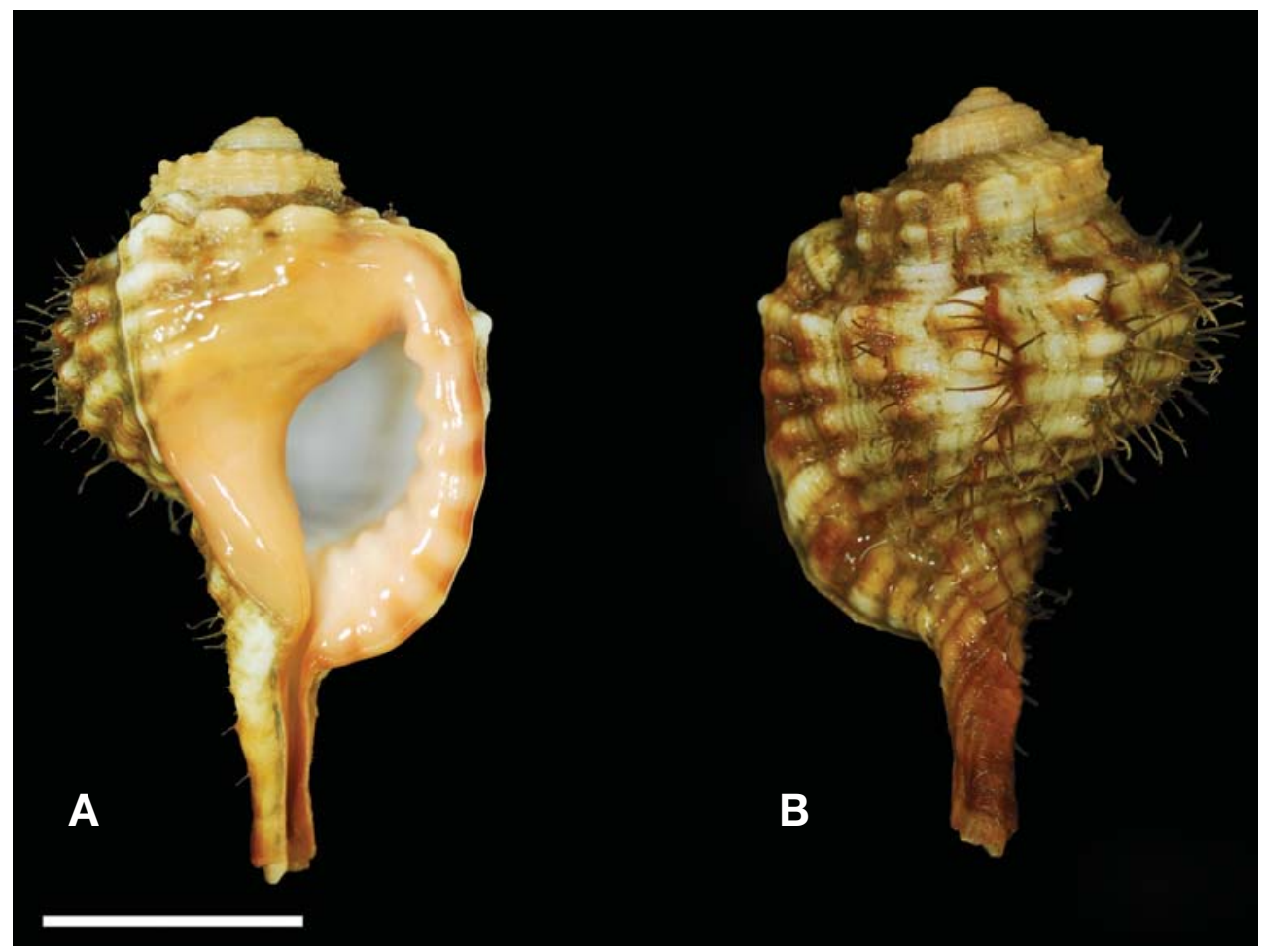

Fig. 1. The shell of Cymatium encausticum (Reeve, 1844). A, Ventral view; B, Dorsal view. Scale bar=20 mm.

Cymatium (Ranularia) encausticum: Beu, 1986: 296, figs. 7880; Henning and Hemmen, 1993: 77, Pl. 16, fig. 1; Poppe, 2008: 648, Pl. 269, figs, 4, 5.

Material examined. 1 individual (collected alive), Jeju-do, Seogwipo-si, Beophwan-dong, Beomseom, depth of $9 \mathrm{~m}$ by scuba diving, 6 Nov 2010.

Measurement. Shell height $57.7 \mathrm{~mm}$; shell width $32.8 \mathrm{~mm}$. Description. Shell solid, club-shaped, whitish brown in color; spire very short accounting for less than 1/4th of shell height; each whorl with thick spiral ribs crossed by axial cords, making the shoulder angulated; body whorl well-developed having 11 axial ribs covered with dark-brown, bristled periostracum; aperture ovate with a prominent posterior canal; parietal wall strongly calloused, extending to shoulder of penultimate whorl; outer lip very thick, red-yellow with seven nodules extending inside outer lip; siphonal canal markedly long (accounting for almost 1/3rd of shell height), narrow, and noticeably recurved backward.

Habitat. Bedrock of 5-10 m deep.

Distribution. Philippine, Taiwan, Vietnam, Japan, and Korea (Jejudo Island).

Remarks. This species is similar to its congener $C$. gutturnium (Röding, 1798) in size and general appearance, but differs from it in a suit of apertural features: the callus of parietal lip in C. encausticum is much more developed, reaching into the shoulder of the penultimate whorl, than in any other congeneric species, including $C$. gutturnium. The axial ribs of this species are less prominent that those found in $C$. gutturnium. This species has been known to occur with $C$. gutturnium, $C$. springsteeni, and C. exile, mostly in tropical seawaters including the Philippine Islands (Beu, 1986). This is the first case report of its occurrence in the Korean waters.

\section{ACKNOWLEDGMENTS}

This work was supported by a grant from Marine Biotechnology Program funded by Ministry of Land, Transport and Maritime Affairs (MMRBK; Marine Mollusk Resource Bank of Korea) of Korean Government.

\section{REFERENCES}

Beu AG, 1986. Taxonomy of gastropods of the families Ranellidae (=Cymatiidae) and Bursidae. Part 2. Descriptions of 14 new modern Indo-West Pacific species and subspecies, with revisions of related taxa. New Zealand Journal of Zoology, 13:273-355. 
Govan H, 1995. Cymatium muricinum and other ranellid gastropods: major predators of cultured tridacnid clams. International Center for Living Aquatic Resources Management, Manila, pp. 1-136.

Habe T, 1964. Shells of the western Pacific in color. Vol. 2. Hoikusha, Osaka, pp. 1-233.

Henning T, Hemmen J, 1993. Ranellidae and Personidae of the world. Verlag Christa Hemmen, Wiesbaden, pp. 1-263.

Houbrick JR, Fretter V, 1969. Some aspects of the functional anatomy and biology of Cymatium and Bursa. Proceedings of the Malacological Society of London, 38:415-429.

Littlewood DTJ, 1989. Predation on cultivated Crassostrea rhizophorae (Guilding) by the gastropod Cymatium pileare
(Linnaeus). Journal of Molluscan Studies, 55:125-127.

Poppe GT, 2008. Philippine marine mollusks. Vol. 1. Gastropoda, part 1. ConchBooks Co., Hackenheim, pp. 1-758.

Reeve LA, 1844. Monograph of the genus Triton. Conchologia Iconica 2, Pls. 1-20.

Yen TC, 1942. A review of Chinese gastropods in the British Museum. Proceedings of the Malacological Society of London, 24:170-289. 